\title{
AN EMPIRICAL ANALYSIS OF ISSUES AND TRENDS IN MANUFACTURING PRODUCTIVITY THROUGH A 30-YEAR LITERATURE REVIEW
}

\author{
C.H. Lee ${ }^{1}$ \& C.S. Leem ${ }^{1 *}$
}

\section{ARTICLE INFO}

$\begin{aligned} & \text { Article details } \\ & \text { Submitted by authors } \\ & \begin{array}{l}\text { Accepted for publication } \\ \text { Available online }\end{array} \\ & \text { 9 Jun } 2016 \\ & 12 \text { Aug } 2016\end{aligned}$
$\begin{aligned} & \text { Contact details } \\ & \text { * Corresponding author } \\ & \text { leem@yonsei.ac.kr }\end{aligned}$
$\begin{aligned} & \text { Author affiliations } \\ & \text { Department of Industrial and } \\ & \text { Information Engineering, } \\ & \text { Yonsei University, Seoul. South } \\ & \text { Korea }\end{aligned}$

DOI

http://dx.doi.org/10.7166/27-2-1363

\section{ABSTRACT}

This paper analysed the keywords in manufacturing productivityrelated studies over the last 30 years to consider the change in the concept of 'productivity', a longstanding and important factor in studies about manufacturing. After first identifying 110,269 keywords in related research through 11,237 academic papers, we narrowed them down to 97 in nine categories by applying certain criteria. Most of the previous studies dealt with productivity in the context of corporate data; but this study investigated the change in the concept of manufacturing productivity by analysing the keywords of many studies of this concept. We classified the 30 years from 1980 to 2009 into five eras of productivity, according to their representative characteristics, using the analysed keywords. We expect that this study will serve as a practical guideline for managers in industry, and as an academic foundation for future research into productivity.

\section{OPSOMMING}

Die sleutelwoorde in die navorsingstudies oor vervaardigingsproduktiwiteit oor die afgelope dertig jaar is geanaliseer om die verandering in die definisie van produktiwiteit as konsep te verstaan. Nadat 110,269 sleutelwoorde in 11,237 navorsingsartikels geïdentifiseer is, is die sleutelwoorde verminder tot 97 wat in nege kategorieë gesorteer is. Dit is gedoen deur sekere kriteria toe te pas. Die meeste van die vorige studies het met produktiwiteit gehandel binne die konteks van korporatiewe data, maar hierdie studie ondersoek die verandering in die konsep van vervaardigingsproduktiwiteit deur die sleutelwoorde van studies oor hierdie konsep. Die tydperk van 1980 tot 2009 is in vyf eras van produktiwiteit geklassifiseer. Die verwagting is dat hierdie studies kan dien as ' $n$ praktiese riglyn vir bestuurders in die industrie en as ' $n$ akademiese grondslag vir toekomstige navorsing oor produktiwiteit.

\section{PRODUCTIVITY IN MANUFACTURING INDUSTRIES}

The concept of productivity developed in the 18th century, when it indicated the ratio between inputs (such as human and non-human resources) and manufacturing processes and outputs (products and services). The concept of productivity expanded over time to various areas and subjects. The most frequently-used macro-economic concept of productivity consists of partial and total factor productivity, and for some time it has been used to measure the corporate competitiveness of certain countries and industries. Partial factor productivity indicates outputs and single inputs, especially the relationship between labour and capital, while total factor productivity means the relationship among multiple inputs and outputs. In addition, various forms of productivity-related analysis have been conducted through Malmquist index and growth accounting analysis [22, 49]. Furthermore, Sharpe [44] compared the concept of productivity with its measurement methods, issues, etc., and Syverson [49] presented small-scale factors that affect productivity in operating 
factories and companies. Moreover, Porter [38] proceeded with a series of studies on the effects of industrial and regional clusters on the improvement of productivity. The effects of such factors as the national economy, industry, companies, and factories on productivity were considered [44].

However, these previous studies overly focused on measuring and analysing productivity, resulting in bounded sets of data such as TFP (total factor productivity). These studies failed to consider the longitudinal meaning of productivity. To overcome this limitation, this study applied an analysis method that could be differentiated from the existing studies, and attempted to develop new findings through this process.

The purpose of this study is to determine the overall trends in productivity-related studies in manufacturing, and to draw conclusions by analysing the keywords of the productivity-related literature. This study also seeks to predict future trends in productivity studies. We expect that these trends will help researchers to review the results of the studies conducted over a given period. To do this, the researcher collected 11,237 productivity-related studies conducted from 1980 to 2009 , based on various perspectives, and abstracted 110,269 keywords from them. With the exception of a few meaningless values, 18 topics with above-average frequency were classified into nine fields of productivity research.

This study has three parts apart from this introduction. Section 2 presents the methodology, including explanations of the data collected to implement the analysis, and the analysis methods and procedures. Section 3 contains the data analysis results, identifies and explains the trends in productivity-related studies that have been emphasised in each period, and presents the manufacturing-related productivity topics that have become increasingly important. Lastly, Section 4 presents the conclusions, limitations, and topics for future research.

\section{THE RESEARCH METHODOLGY}

To analyse the flow of productivity-related studies, we selected 11,237 papers for the 30 -year period from 1980 to 2009 as the scope of this study. This has enabled us to discern what kind of productivity has been regarded as important, and what changes have occurred during the period, by analysing the wide range of keywords in these studies over that time. The procedures we used to identify the keyword categories are shown in Figure 1.

Phase 1 collected the productivity-related studies and abstracted keywords from them. To collect the papers to be analysed in this study, we searched the Scopus database for 'productivity' and 'manufacturing'. The Scopus database includes academic essays that have been published worldwide, including many journals concerned with productivity-related studies; and so this collection of papers can be regarded as representative [17]. The search returned 11,237 papers for the given 30-year period. Of those papers, some 1,657 contained no keywords. We abstracted 110,269 keywords from the remaining 9,580 papers. This total included repeated keywords.

In Phase 2 we normalised the collected keywords, based on their respective frequencies of occurrence. We removed 23,745 keywords that had appeared only once, as we assessed these as meaningless. We narrowed down the remaining 86,524 to 8,295 keywords by dropping the keywords with frequencies below an average value of 10.4. We regarded 1,294 keywords that were used more than 10 times as highly important. In order to establish a more general and objective perspective on productivity itself, we eliminated the keywords that related specifically to a nation or industry, or those that referred to an irrelevant form of productivity. At the end of this elimination process, 379 keywords remained. Finally, we eliminated overlapping keywords by manually inspecting each keyword. This final step yielded 95 keywords.

In Phase 3 we categorised and analysed those 95 keywords through a focused group interview (FGI) process with the research staff who had conducted productivity-related studies. Nine keyword categories were established as result of this process. Assuming that the number of research papers increases linearly, we chose the five categories with the highest yearly variance by using $\mathrm{R}^{2}$, and identified them as the five eras of manufacturing productivity. Then, by exploring the distribution and content of the studies that include the keywords, we were able to locate the representative research topics of each era. 
Through normalising the productivity-related keywords, 95 keywords were selected as the subject of further analysis. These keywords were divided into nine categories: Automation, Cost, Energy, Environment, Information, Innovation, Labour, Process, and Quality. Table 1 sets out the keyword categories and their relationships with productivity enhancement.

The Automation category included keywords that represented manufacturing automation technologies and systems that affect the improvement of productivity, such as advanced manufacturing technology and agile manufacturing systems. The Cost category illustrated methods of cost accounting and cost reduction. The Energy and Environment categories mainly dealt with enhancing energy efficiency or protecting the environment. These categories were mainly concerned with international and domestic regulations. The Information category's keywords related to information systems for improving decision-making and information management in manufacturing companies. Keywords about productivity improvement through technological innovation and the use of intellectual property were placed in the Innovation category. Keywords linked to productivity improvement through the input of the labour force and the education of human resources were allocated to the Labour category. Finally, the Process and Quality categories include keywords related to techniques and management processes for improving product quality and flow of inventory.

Phase I. Selection of productivity-related research

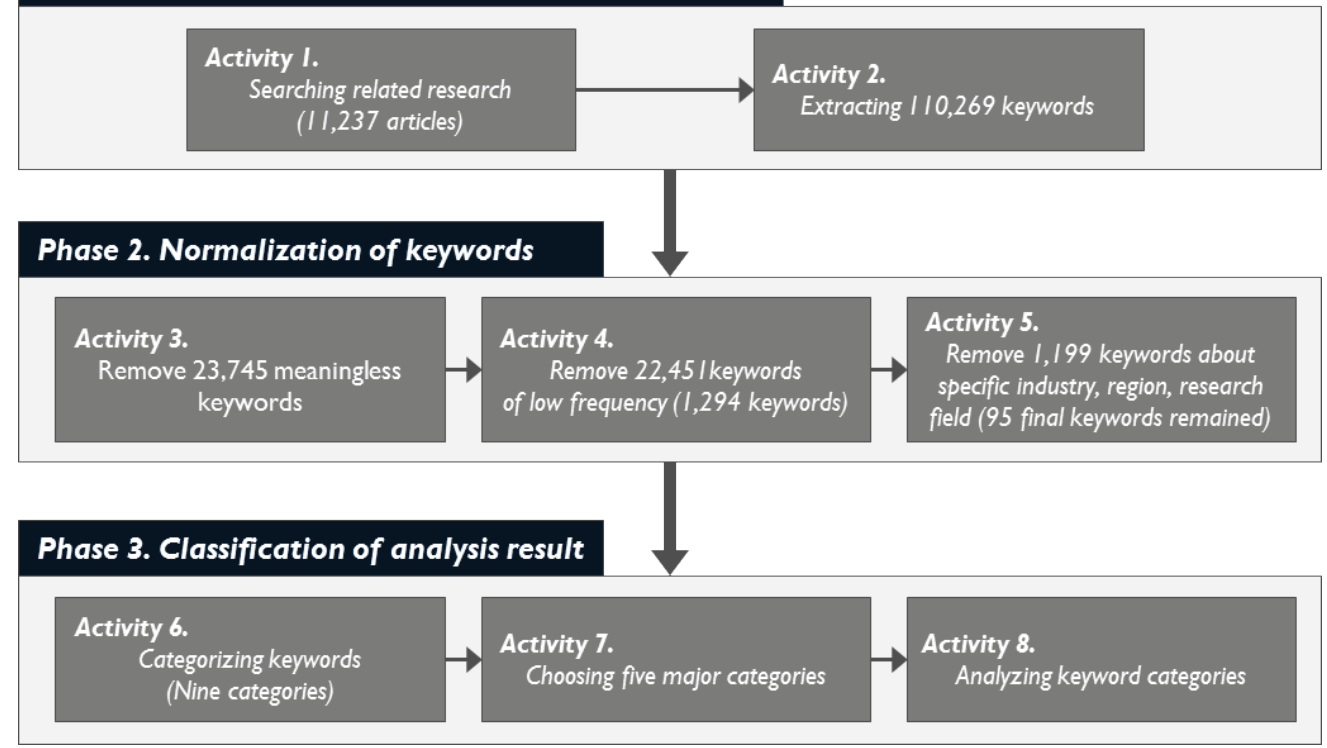

Figure 1: Procedures followed to identify keyword categories

In addition, by inductive inference we identified eighteen topics underlying the improvement of manufacturing productivity, based on the characteristics of the keywords in each of the nine categories. Figure 2 shows the eighteen factors and how they relate to the nine categories. For example, the Automation category relates to the topics of Flexible Manufacturing and Computeraided Manufacturing. Flexible Manufacturing contains keywords that relate to utomation that enhance flexibility, such as agile manufacturing, agile manufacturing systems, flexible automation, and flexible manufacturing systems. Computer-aided Manufacturing was composed of keywords that supported efficiency and productivity by computer systems, such as advanced manufacturing technology, automated manufacturing, automated manufacturing systems, automated systems, automation, computer-aided manufacturing, computer-aided production, design for manufacturing (DFM), equipment, factory automation, machine tools, and manufacturing automation. The remaining sixteen topics were generated in a similar way. 


\subsection{Research trends in manufacturing productivity}

The overall trend in research papers related to manufacturing productivity was determined by tracking the number of studies in the SCOPUS database that included both 'manufacturing' and 'productivity' in their title or keyword, as shown in Figure 3. The emerging pattern showed that in the mid-1980s the number of papers related to manufacturing productivity increased sharply, followed by a drastic decrease, reaching a low in the late 1980s. Another highlight is the evident steady increase from 1993, reaching a peak in the mid-1990s. A further drastic increase in the number of papers on manufacturing productivity is evident from the late 1990s, reaching an all-time high in 2004, after which they declined once more.

Table 1: Categories derived from productivity-related keywords

\begin{tabular}{|c|c|c|}
\hline $\begin{array}{l}\text { Keyword } \\
\text { category }\end{array}$ & Description & Included keywords \\
\hline Automation & $\begin{array}{l}\text { Manufacturing automation } \\
\text { technologies and systems } \\
\text { that affect the improvement } \\
\text { of productivity }\end{array}$ & $\begin{array}{l}\text { Advanced manufacturing technology, Agile } \\
\text { manufacturing, Agile manufacturing systems, } \\
\text { Automated manufacturing, Automated manufacturing } \\
\text { systems, Automated systems, Automation, Computer- } \\
\text { aided manufacturing, Computer-aided production, } \\
\text { Design For Manufacturing (DFM), Equipment, Factory } \\
\text { automation, Flexible automation, Flexible } \\
\text { manufacturing systems, Machine tools, Manufacturing } \\
\text { automation }\end{array}$ \\
\hline Cost & $\begin{array}{l}\text { Calculation and reduction of } \\
\text { production costs }\end{array}$ & $\begin{array}{l}\text { Activity-based costing, Cost accounting, Cost } \\
\text { effectiveness, Cost reduction, Costs, Production cost }\end{array}$ \\
\hline Energy & $\begin{array}{l}\text { Enhancement and } \\
\text { management of energy } \\
\text { efficiency }\end{array}$ & $\begin{array}{l}\text { Energy conservation, Energy consumption, Energy } \\
\text { efficiency, Energy management, Energy policy, Energy } \\
\text { utilization }\end{array}$ \\
\hline Environment & $\begin{array}{l}\text { Regulations and } \\
\text { management for protecting } \\
\text { the environment }\end{array}$ & $\begin{array}{l}\text { Environment, Environmental impact, Environmental } \\
\text { management, Environmental protection, Environmental } \\
\text { regulations, Pollution control }\end{array}$ \\
\hline Information & $\begin{array}{l}\text { Information systems for } \\
\text { improving decision-making } \\
\text { and information } \\
\text { management of } \\
\text { manufacturing companies }\end{array}$ & $\begin{array}{l}\text { Company information, Database systems, Decision } \\
\text { support systems, Electronic data interchange, } \\
\text { Enterprise resource planning, Information management, } \\
\text { Information systems, Information technology, } \\
\text { Management information systems, Manufacturing } \\
\text { execution systems (MES), Real time systems }\end{array}$ \\
\hline Innovation & $\begin{array}{l}\text { The improvement of } \\
\text { productivity through } \\
\text { technological innovation and } \\
\text { use of intellectual property }\end{array}$ & $\begin{array}{l}\text { Innovation, Intellectual property, Knowledge } \\
\text { acquisition, Knowledge-based systems, Knowledge } \\
\text { management, Patents and inventions, Technological } \\
\text { innovation, Spillover effect, Technological change, } \\
\text { Technological development, Technology, Technology } \\
\text { adoption, Technology transfer }\end{array}$ \\
\hline Labour & $\begin{array}{l}\text { The improvement of } \\
\text { productivity through the } \\
\text { input of the labour force and } \\
\text { the education of human } \\
\text { resources }\end{array}$ & $\begin{array}{l}\text { Education, Employee, Employment, Empowerment of } \\
\text { personnel, Human capital, Human resources, Human, } \\
\text { Personnel training, Personnel }\end{array}$ \\
\hline Process & $\begin{array}{l}\text { Techniques for improving } \\
\text { and managing manufacturing } \\
\text { processes }\end{array}$ & $\begin{array}{l}\text { Cellular manufacturing, Continuous improvement, } \\
\text { Inventory control, Inventory management, Just-in-time, } \\
\text { Lean manufacturing, Manufacturing process, Process, } \\
\text { Process control, Process design, Process development, } \\
\text { Process engineering, Process improvement, Process } \\
\text { monitoring, Process optimisation, Process planning, } \\
\text { Production process, Scheduling, Statistical process } \\
\text { control }\end{array}$ \\
\hline Quality & $\begin{array}{l}\text { Management activities and } \\
\text { techniques for improving } \\
\text { product quality }\end{array}$ & $\begin{array}{l}\text { Product quality, Quality, Quality assurance, Quality } \\
\text { control, Quality improvement, Quality management, } \\
\text { Reliability, Total quality control, Total quality } \\
\text { management }\end{array}$ \\
\hline
\end{tabular}




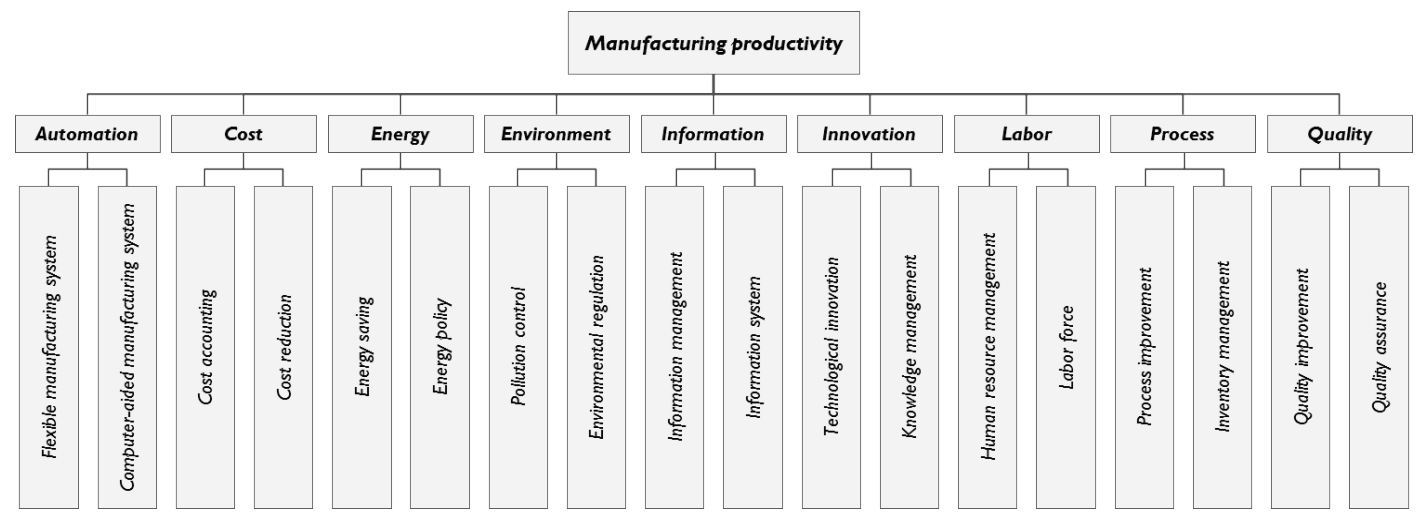

Figure 2: Eighteen inferred topics for improving manufacturing productivity

Before the 1980s, the intensity of labour/capital inputs and the efficiency of outputs relative to input were emphasised. Trade protection was prevalent, and improved productivity was pursued through economies of scale. The scope of management was at the regional or national level, and the labour force, simple facilities, and investment based on capital were the important bases of production. To increase productivity, developing countries emphasised expanding the amount of labour, procuring and intensifying investment capital, and increasing savings and investment ratios [13]. A unilateral mass production, driven by companies was implemented, and they could realise a high productivity level in economy of scale [1].

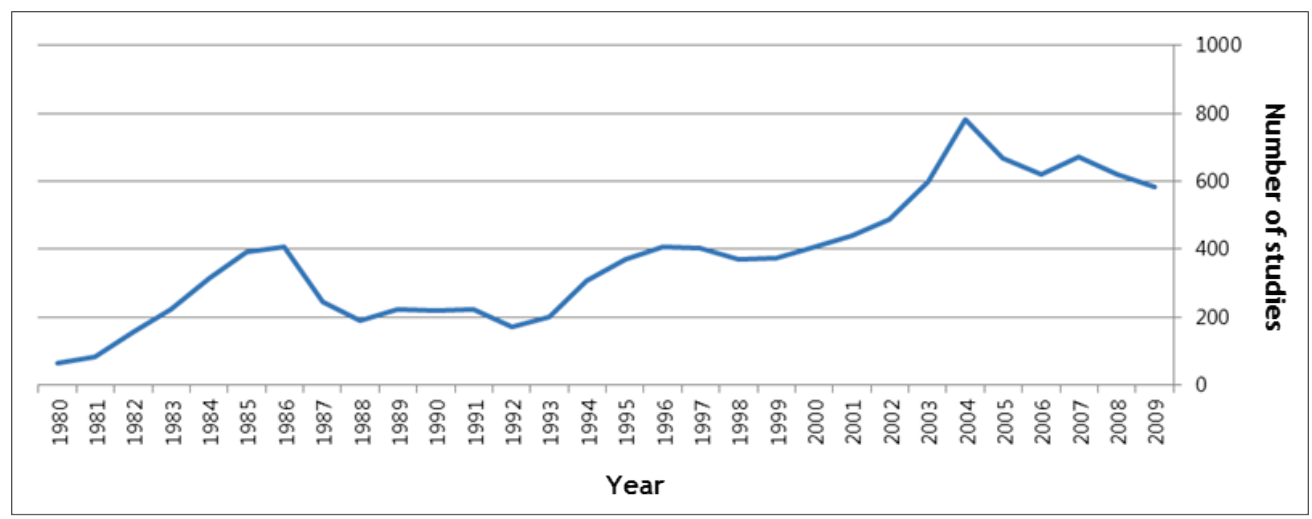

Figure 3: Increase in manufacturing productivity-related studies

In the 1980s, expanded international trade triggered intensified competition. Productivity was enhanced by quality improvement applied to advanced systems, along with growing interest in production technology. Furthermore, as technology developed and expectations about quality increased, skilled workers emerged. Companies began to pay more attention to the production methods and processes that had evolved gradually from the previous simple manual processes. In particular, automation emerged to increase productivity in labour-intensive industries, and led to the expansion of advanced technology for job diversification [34]. In addition to automation, the spread of microcomputers in the 1980 s had a great effect on improved productivity in manufacturing and production [41]. Factories became automated, and studies on the improvement of manufacturing efficiency and management technologies were conducted. Moreover, policy-related studies for promoting small companies were conducted, related to the evolution of manufacturing technologies [6].

In the early 1990s, companies concentrated on the effects of international competition, lower trade barriers, technological innovation, and an increase in the demand for low-price/high-quality goods. Companies tried to guarantee customer satisfaction and reliability by managing the characteristics of their goods and services [8]. Thus statistical management for quality, not simply increasing output, became a main research subject [28]. The management of human resources grew in importance, along with an increased focus on effective processes and production methods. Some 
studies showed that feedback between colleagues had a positive effect on efficiency and quality, and that it could motivate workers to enhance their performance, resulting in synergy [43].

During the 2000s, companies paid more attention than ever before to the integration of manufacturing technologies with IT. Thus it became easier to measure such factors as the improvement of productivity, fast response times, and flexibility [16]. Employees in companies came to need more information and to use devices for better communication. Companies increased efficiency by providing their employees with better information, which thus improved productivity [18].

From the mid-2000s, new management methods such as cross-functional and knowledge-intensive business processes became important in pursuing international competitiveness. As it emerged that the dispersion of knowledge contributed to improving product quality and productivity, the importance of research and development (R\&D) was emphasised, stimulating innovation [36]. Knowledge management rose sharply as a new strategy for productivity improvement. Innovation realised through the creation of knowledge played a significant role in enhancing company performance [10].

As the product cycle shortened, environmental problems increased accordingly, alongside the dispersion of knowledge, R\&D, and innovative activities. So the manufacturing industry concentrated on issues related to environmental regulations, including studies of the effect of enhanced environmental regulations on new technology development and R\&D investment [27]. Several manufacturing firms have looked at cleaner production as a way to maintain environmental practices and their competitive advantage [51]. In addition, some leading countries emphasised the necessity of establishing a strategy to decrease energy consumption through a series of studies on strategies and technologies about energy reduction.

We used the R-squared value of a regression analysis to understand the affinity between the nine keyword categories (Automation, Cost, Energy, Environment, Information, Innovation, Labour, Process, and Quality). We used the linear regression function of SPSS 21 to acquire the numerical data of the relevant characteristics of manufacturing productivity in a particular period. The Rsquared value produced by the regression analysis indicates the degree that the estimated values of the regression expression and the data correspond to each other, and consists of the range from 0 to 1 . The closer to 1 the R-squared value is, the higher the explanation of the regression expression. In other words, a low R-squared value means low correlation between the two variables.

In this study, R-squared analysis is used to select categories that explain the characteristic of productivity in a particular period. As a result of the regression analysis, the Automation, Quality, Process, Information, and Innovation keyword categories had R-squared values below 0.5 , indicating that these categories are relatively independent of each other. A low R-squared value denotes a high variance in linear regression, indicating a sudden distortion or fluctuation of values. We interpreted these movements of points as notable events, and identified them as the five eras of manufacturing productivity.

Table 2: R-squared of nine categories

\begin{tabular}{|c|c|c|}
\hline Keyword & Number of related keywords & $R$-squared \\
\hline Automation & 16 & 0.0965 \\
\hline Quality & 9 & 0.4769 \\
\hline Process & 19 & 0.4749 \\
\hline Information & 11 & 0.4954 \\
\hline Innovation & 13 & 0.4567 \\
\hline Cost & 6 & 0.5268 \\
\hline Labour & 9 & 0.5423 \\
\hline Energy & 6 & 0.6585 \\
\hline Environment & 6 & 0.6579 \\
\hline
\end{tabular}

\subsection{The five eras of categories of manufacturing productivity}

To analyse the historical trends of manufacturing productivity, five eras were analysed by computing the sum of the keywords in these eras for each year from 1980 to 2009. This sum illustrates the progression in the number of papers, but does not present the characteristics of the trends. Thus the volume of the studies in the five categories were analysed to determine which keywords had 
been used most frequently. This is shown in Figure 4, which describes the portion of the categories for each year, based on the number of keywords. Figure 4 shows that many of the studies on the improvement of productivity as Automation were conducted from 1980 to 1987 . Quality was the subject of various studies from 1991 to 1996, and Process grew in emphasis from 1996 to the end of the 20th century. Studies on Information were actively conducted from the early 2000s to the mid2000 s, and Innovation played a key role from the mid-2000s to the end of the 2000s.

Figure 5 analyses the yearly distribution of the number of keywords compared with the total numbers of papers in each category. We can see when the studies in each category were actively conducted during the period 1980 to 2009, and can understand the trends among them.

\subsubsection{The 'automation' era}

The automation era accompanied a great emphasis on improving productivity. Automation-related studies increased rapidly from 1980 to 1985 , yet a gradual decrease followed in the early 1990 s. After 2000 researchers' interest in this concept slowly declined.

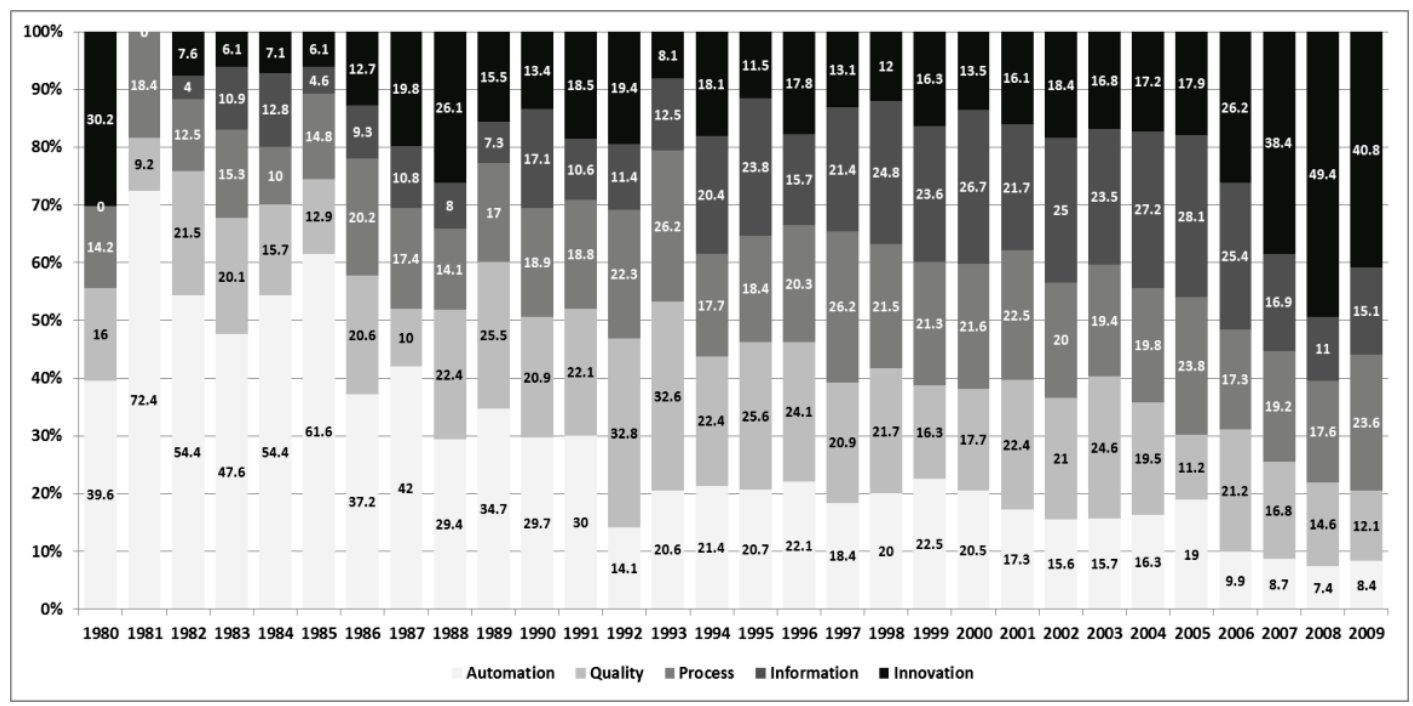

Figure 4: The five eras of manufacturing productivity

Influential studies on Automation include the following. Nitzan and Rosen [34] emphasised that programmable automation could adapt to the changing needs of diversity of products and volume in mass production costs. The ultimate purpose of programmable automation is improved efficiency through the integrated production using computers. Sohal [46] studied the investment results of advanced manufacturing technologies (AMT). Companies invest in AMT such as computer software, hardware, plants, and equipment to achieve a competitive advantage. A series of studies suggested that it would be necessary to plan a long-term strategy for AMT investment in order to predict profits.

Mital et al. [32] emphasised that worker training is necessary to take full advantage of AMT. In addition to the automation of process, agile manufacturing also emerged to provide cost-effective products promptly. Gunasekaran [15] defined the core concept of agile manufacturing, and published a study presenting a conceptual framework for developing it.

\subsubsection{The 'quality' era}

The quality era could be defined as that era when quality management activities were highly regarded as enhancing productivity. Until 1990, quality studies did not exceed two per cent of the total number of studies. However, the studies gradually increased in the 1990s relative to the other concepts of productivity. After the mid-1990s they showed a pattern similar to that of the overall research related to productivity.

Demand for high quality products at low prices increased as international competition intensified and innovation in manufacturing accelerated [6]. Investment in flexible manufacturing systems (FMS) led to reduced payrolls and other costs, and to lower production lead-times with increased output and flexibility [8]. Lawrence and Hottenstein [28] asserted that the just-in-time (JIT) production 
method in particular had a positive effect on improved productivity, quality, lead-time, and customer service. Several researchers suggested that companies needed to improve quality and productivity [4, 33, 35].

\subsubsection{The 'process' era}

The process era featured improved processes and their associated management techniques had an effect on productivity. When we examine the distribution of studies in this period, we discover that the Process category amounted to about one per cent in the 1980s, and that the trend increased steadily until 1995 (Figure 5). While other concepts of productivity decreased from 1996 to 1998 , research on process slowly increased.

Some examples of studies on Process follow. Lieberman and Demeester [30] emphasised the application of the JIT method, which provided products in a timely manner when necessary without any inventory. It improved productivity by solving such problems as increasing inventories, machinery malfunctions, faulty products, and increased set-up time. During the 2000s, researchers performed a series of studies to enhance the effectiveness of company-wide processes. Continuous improvements - a consistent improvement of organisational processes to enhance the basic integrity of organisational culture, such as trust and communication - is a representative topic in the process era. Terziovski and Sohal [50] suggested an emphasis on internal communication and cooperation between groups of firms.

Total productive manufacturing (TPM), a technique to improve productivity by improving the function and design of production facilities, had positive effects on organisational performance: quality, productivity, cost reduction, and delivery reliability. TPM can remove the necessity to invest in new plant and equipment. Chan et al. [7] found that it would be necessary to establish guidelines and organise a TPM team to effectively implement TPM. Organisational commitment and a continuous upgrading of education systems were also required.

Six-sigma began to be emphasised from the mid-2000s as a technique for product quality improvement and cost reduction by production process control. Kumar et al. [25] suggested that, when companies introduced this technique, they could improve the process by removing ineffective factors to increase productivity in the manufacturing process.

\subsubsection{The 'information' era}

The information era occurred when manufacturing companies actively tried to improve manufacturing performance and productivity by using their decision-making and information technology (IT) systems. Studies on Information were scarce until the 1990s, but they became more frequent from the mid-1990s, especially from 1993 to 1995. They then showed no clear trend until the early 2000 s, but they generally received a high level of attention.

Despite the IT productivity paradox, which states that increased investment in IT has little effect on productivity, many scholars proceeded in the early 1990s with studies that emphasised the importance of information and IT. Lee and Baura [29] suggested that the application of information technology would promote an accumulation of capital and improve productivity. They also asserted that the contribution of investment in IT was being undermined by the pre-existent ineffectiveness of production. As corporate management by information technology grew, the importance of the integration of IT and enterprise strategy was emphasised in the company-wide perspective. Sohal et al. [47] asserted that it would necessary to secure strategic cooperation between IT departments and top management. Soliman et al. [48] emphasised the role of enterprise resource planning (ERP) in improving the overall effectiveness of the company, such as the decision-making process and communication among departments.

\subsubsection{The 'innovation' era}

The innovation era occurred when manufacturing companies enhanced their productivity not only with innovating technologies but also with management skills, and by making the most of their intellectual property. Innovation studies followed the pattern of other categories, except for the automation-related studies in the 1980s. In the 1990s, however, innovation studies were relatively infrequent. Even in early 2000s they did not receive much attention from researchers; but in the mid-2000s quite a different pattern emerged. Innovation-related keywords were presented in the field of manufacturing productivity, showing a weight of up to 12 per cent, and the trend remained the same until the end of the 2000s. 
Innovation enables companies to respond to customer demands promptly and accurately, and to carry out customer satisfaction management [9]. Baldwin and Gu [3] maintained that innovative companies were quick to acquire information and employ advanced technologies, allowing them to enter export markets easily. Product differentiation by innovation produces positive results as its productivity grows. They explained that the companies implementing knowledge management could achieve innovation and improve productivity by the efficient allocation of resources [10]. Lanoie et al. [27] and Zhang et al. [52] argued that technological innovation that resulted from external stimuli, such as environmental regulations, might enhance corporate competitiveness and affect international trade and investment by securing the priority of productivity.

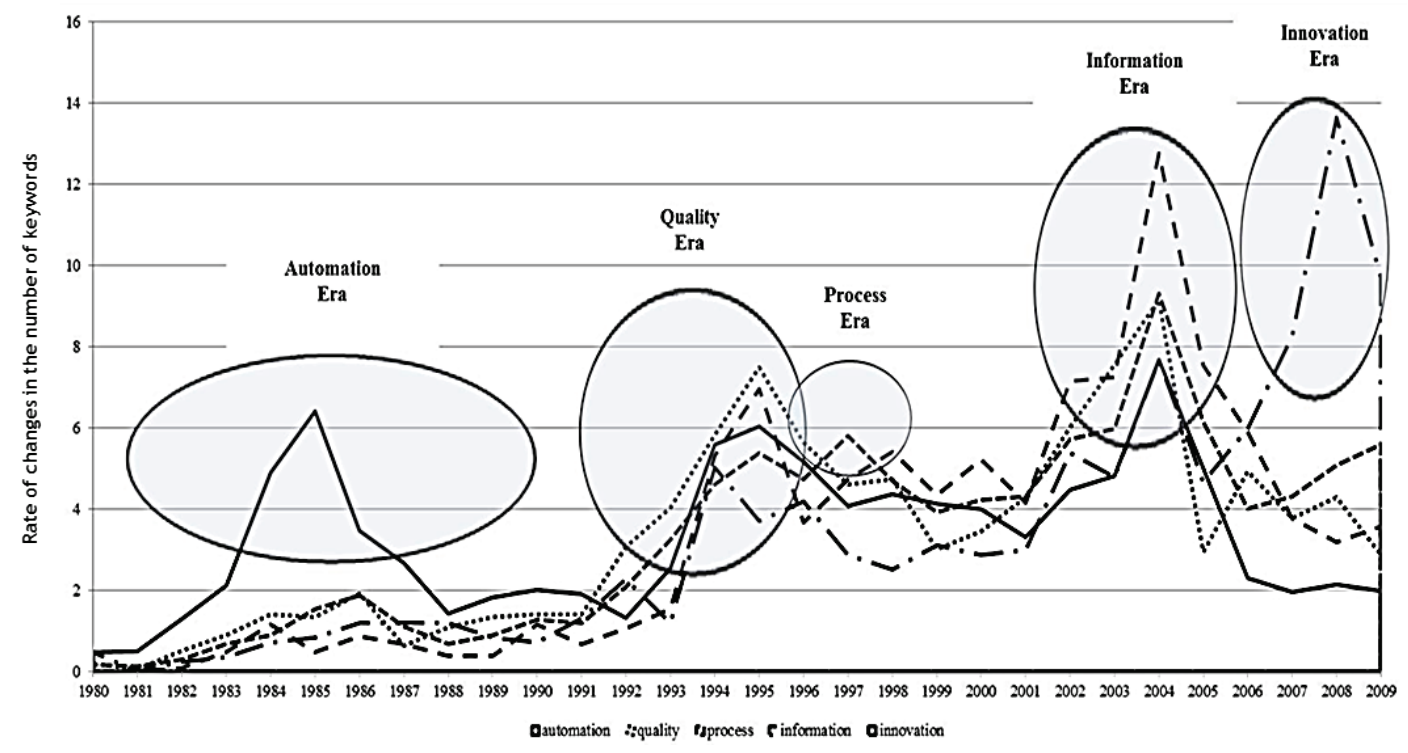

Figure 5: The five eras of manufacturing productivity

\subsection{The other trends about productivity}

We conducted an additional analysis of the remaining four of the nine keyword categories related to productivity: Cost, Energy, Environment, and Labour. Cost and Labour were grouped as the traditional elements of productivity, while Environment and Energy were grouped as the emerging elements of productivity. We expanded the scope of the Energy and Environment categories to the year 2012, collecting more new terms.

\subsubsection{Labour and Cost}

Labour and Cost play a significant role in productivity improvement, even though these categories failed to meet our R-squared threshold. We therefore performed an additional analysis to investigate their trends.

The studies on Labour involved various approaches. Researchers in the 1980s mainly selected a time series analysis, and Hulten and Schwab [20] demonstrated the importance of labour for its effect on corporate performance through an analysis of the 1951-1978 data of manufacturing companies in the Unites States. Furthermore, Dollar and Wolff [12] analysed the degree of labour intensity in manufacturing industry, using data from 1963 to 1982. Much labour-related research was conducted in the 1990s. Dollar and Sokoloff [11] emphasised the importance of labour to improving productivity and increasing the size of assets in the manufacturing industry. In the same period, many studies concerned worker education and training.

In particular, the participation of an active worker in a dynamic, competitive environment could improve company performance and productivity [21, 39]. Drucker [14] mentioned knowledge workers who use and create knowledge through their work. When knowledge worker tried to solve a task by themselves, they could deal with the work efficiently and to their satisfaction. Labour could contribute to the improvement of an organisation's productivity. Mital et al. [32] emphasised that, to increase the effectiveness of utilities and technologies in an AMT production system, worker training would be necessary, and that it could enhance a nation's competitiveness. 
As international trade increases, more cost-effective products need to be developed, and if companies use manufacturing systems to produce various types of products, that would have a positive effect on productivity and costs $[15,24]$. Technologies and facilities in manufacturing were represented by JIT, which would lower unit costs and improve profits. Lowering manufacturing costs through new technologies has improved international competitiveness and productivity [5, 45]. Furthermore, manufacturers adopted flexible cost structures to reduce inventory cycle through price control. These changes had a positive effect on the productivity of manufacturing firms [16].

\subsubsection{Energy and Environment}

As awareness grew of climate and environment issues, such as the destruction of the ozone layer and the regulation of greenhouse gases, international agreements - such as including the Montreal Protocol in 1989 and the International Climate Conference in 1992 - emerged to address them. In 1994 the international community began to deal with environmental concerns, and the Committee on Trade and Environment was established by the World Trade Organization. In 1997, the Kyoto Protocol of the Climate Change Convention was an attempt to slow global warming. Companies tried to address these concerns by reducing the contaminants produced in manufacturing.

In the 2000s the number of environment-related research papers on productivity increased dramatically. As many companies chose environmentally-friendly production methods, many studies focused on the topic [40]. Zhang et al. [52] introduced environmentally conscious design and manufacturing (ECD\&M), an environmentally-friendly, cost-effective method to reduce the effects of toxic substances and disposal expenses.

In the second half of the 2000s many researchers studied production methods that might simultaneously enhance manufacturing productivity and meet environmental regulations. Lanoie et al. [27] studied the relationship between environmental regulations and total factor productivity. Furthermore, many companies have recently practised clean production (CP) to enhance their competitiveness and to protect the environment, and this has had a positive effect on corporate productivity [51]. Companies also developed new frameworks to evaluate the environmental, social, and economic sustainability of operational processes in the manufacturing business in relation to the environment $[23,26]$.

Oil prices, which were relatively stable in the 1980s and 1990s, have risen since 2003, and a worldwide shortage of both oil and energy resulted. Accordingly, many countries established nationwide energy policies. In the U.S., President George W. Bush established the National Energy Policy Development (NEPD). In 2002 Japan adopted the Energy Policy Act. In 2006 the EU attempted to reduce greenhouse gases by establishing the Strategic Energy Technology (SET) plan and the Energy Technology Perspectives (ETP) of 2012 tried to find technological alternatives to achieve sustainability.

Many studies on energy related to manufacturing have been conducted recently. Those conducted in the 1990s focused on conceptual explanation and use of energy. Howarth et al. [19] investigated the use of energy in manufacturing by the OECD member countries, and Adenikinju [2] showed that there was no relationship between saving energy and productivity. Most of the companies that improved productivity chose to use energy rather than save it. He also investigated the relationship between energy policies and profitability.

In the 2000s, studies directly related to manufacturing productivity began to increase. Schipper and Grubb [42] studied the correlation between the degree of energy intensity and operational efficiency, and Park et al. [37] investigated energy consumption reduction policies that various leading countries have been implementing, energy saving methods, and other topics. Moreover, environment-friendly management stimulated energy reduction and achieved productivity improvement. In conclusion, the companies that institute environment-friendly management continue to improve their energy efficiency and productivity [31].

\section{CONCLUSION AND FUTURE RESEARCH}

In this paper we identified the most common productivity issues by collecting keywords that appeared in a large library of productivity studies, and by grouping them according to their characteristics and content. We evaluated the changing level of keywords, using their R-squared 


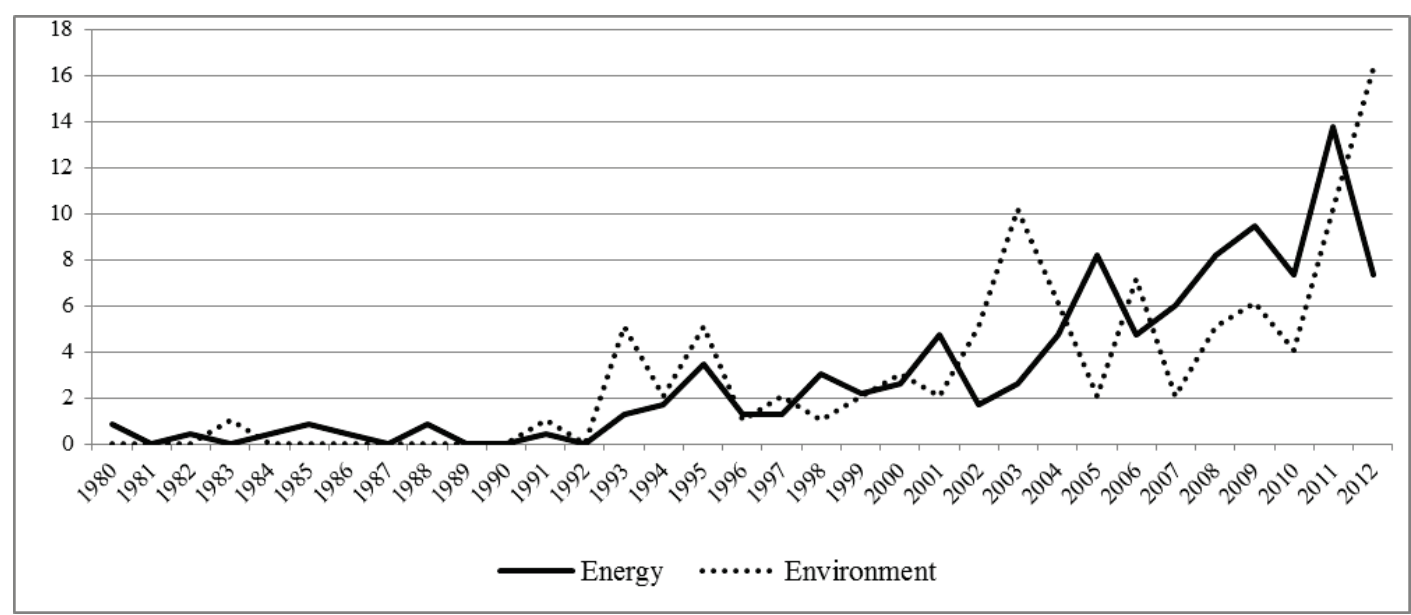

Figure 6: Trends on Environment- and Energy-related keywords

values, in order to analyse the overall trend of productivity-related studies conducted in manufacturing, and grouped them into five eras and eighteen productivity issues. The main results are the following:

- We identified the period when each issue was dealt with in a major way, and ranked them chronologically. The five eras were Automation, Quality, Process, Information, and Innovation. The studies mainly concerned with the effect of Automation on improved productivity were conducted in the Automation era, from 1980 to 1987. In the Quality era, from 1991 to 1996, quality control activities and management techniques for the products of manufacturing companies were given the most attention. In the Process era, from 1996 to the end of the 1990 s, studies on process improvement and the management techniques of manufacturing companies were conducted. During the Information era, from the early 2000 s to the mid-2000s, studies on decision-making and information management were continuously conducted. In the Innovation era, studies on the innovation of manufacturing technologies and intellectual property were conducted. These have been conducted since the mid-2000s, and continue to be important.

- The nine categories of productivity were classified according to the characteristics of the keywords included in each category. The 18 keywords were: flexible manufacturing system, computer-aided manufacturing system, cost accounting, cost reduction, energy saving, energy policy, pollution control, environmental regulation, information management, information system, technological innovation, knowledge management, human resource management, labour force, process improvement, inventory management, quality improvement, and quality assurance.

The results of this research could be used in the following ways:

- The five eras of manufacturing productivity could inspire related research. Earlier research on productivity mainly dealt with specific subjects and technologies. Our main purpose was the investigation of trends across a wide range of scope and subjects.

- Practitioners could use the findings of this research to improve the productivity of their manufacturing facility. All 18 issues may prove useful for problem-solving in various situations involving productivity enhancement.

The time horizon of our study was from 1980 to 2009. We believe that it will be necessary to discuss the traditional factors of productivity, including labour and capital, to expand the scope of analysis for future studies on this domain. We also think that the correlation between the keywords in each category could be determined in order to identify and rank them. Furthermore, this study could contribute to the analysis of strategic tasks in order to achieve improved productivity, as a basis for further research. 


\section{REFERENCES}

[1] Åberg, Y. 1973. I. Regional productivity differences in Swedish manufacturing. Regional and Urban Economics, 3 (2), pp. 131-155.

[2] Adenikinju, A.F. 1998. Productivity growth and energy consumption in the Nigerian manufacturing sector: A panel data analysis. Energy Policy, 26 (3), pp. 199-205.

[3] Baldwin, J.R. \& Gu, W. 2004. Trade liberalization: Export-market participation, productivity growth, and innovation. Oxford Review of Economic Policy, 20(3), pp. 372-392.

[4] Bititci, U.S., Suwignjo, P. \& Carrie, A. 2001. Strategy management through quantitative modelling of performance measurement systems. International Journal of Production Economics, 69(1), pp. 15-22.

[5] Byrd, J. 2004. You made manufacturing productivity grow. SOC Manufacturing Engineers One SME Drive, PO Box 930, Dearborn MI 48121-0930, USA.

[6] Carlsson, B. 1989. The evolution of manufacturing technology and its impact on industrial structure: An international study. Small Business Economics, 1(1), pp. 21-37.

[7] Chan, F., Lau, H., Ip, R., Chan, H. \& Kong, S. 2005. Implementation of total productive maintenance: A case study. International Journal of Production Economics, 95(1), pp. 71-94.

[8] Chen, F.F. \& Adam Jr, E.E. 1991. The impact of flexible manufacturing systems on productivity and quality.IEEE Transactions on Engineering Management, 38(1), pp. 33-45.

[9] Chenhall, R.H. 1996. Strategies of manufacturing flexibility, manufacturing performance measures and organisational performance: An empirical investigation. Integrated Manufacturing Systems, 7(5), pp. 2532.

[10] Darroch, J. 2005. Knowledge management, innovation and firm performance. Journal of Knowledge Management, 9(3), pp. 101-115.

[11] Dollar, D. \& Sokoloff, K. 1990. Patterns of productivity growth in South Korean manufacturing industries, 1963-1979. Journal of Development Economics, 33(2), pp. 309-327.

[12] Dollar, D. \& Wolff, E.N. 1988. Covergence of industry labour productivity among advanced economies, 1963-1982. The Review of Economics and Statistics, pp. 549-558.

[13] Domar, E.D. 1946. Capital expansion, rate of growth, and employment. Econometrica, Journal of the Econometric Society, pp. 137-147.

[14] Drucker, P.F. 1999. Knowledge-worker productivity: The biggest challenge. The Knowledge Management Yearbook 2000-2001.

[15] Gunasekaran, A. 1998. Agile manufacturing: Enablers and an implementation framework. International Journal of Production Research, 36(5), pp. 1223-1247.

[16] Helo, P. 2004. Managing agility and productivity in the electronics industry. Industrial Management \& Data Systems, 104(7), pp. 567-577.

[17] Hildreth, C.R. 1997. The use and understanding of keyword searching in a university online catalog. Information Technology and Libraries, 16(2), pp. 52-62.

[18] Hong, P., Vonderembse, M.A., Doll, W.J. \& Nahm, A.Y. 2005. Role change of design engineers in product development. Journal of Operations Management, 24(1), pp. 63-79.

[19] Howarth, R.B., Schipper, L., Duerr, P.A. \& Ström, S. 1991. Manufacturing energy use in eight OECD countries: Decomposing the impacts of changes in output, industry structure and energy intensity. Energy Economics, 13(2), pp. 135-142.

[20] Hulten, C.R. \& Schwab, R.M. 1984. Regional productivity growth in US manufacturing: 1951-78. The American Economic Review, 74(1), pp. 152-162.

[21] Huselid, M.A. 1995. The impact of human resource management practices on turnover, productivity, and corporate financial performance. Academy of Management Journal, 38(3), pp. 635-672.

[22] Kendrick, J.W. 1954. National productivity and its long-term projection. In Long-Range Economic Projection, 67-104. NBER.

[23] Ketola, T. 2010. Five leaps to corporate sustainability through a corporate responsibility portfolio matrix. Corporate Social Responsibility and Environmental Management, 17(6), pp. 320-336.

[24] Koren, Y., Hu, S.J. \& Weber, T.W. 1998. Impact of manufacturing system configuration on performance. CIRP Annals - Manufacturing Technology, 47(1), pp. 369-372.

[25] Kumar, M., Antony, J., Singh, R., Tiwari, M. \& Perry, D. 2006. Implementing the Lean Sigma framework in an Indian SME: A case study. Production Planning and Control, 17(4), pp. 407-423.

[26] Labuschagne, C., Brent, A.C. \& Van Erck, R.P. 2005. Assessing the sustainability performances of industries. Journal of Cleaner Production, 13(4), pp. 373-385.

[27] Lanoie, P., Patry, M. \& Lajeunesse, R. 2008. Environmental regulation and productivity: Testing the Porter hypothesis. Journal of Productivity Analysis, 30(2), pp. 121-128.

[28] Lawrence, J.J. \& Hottenstein, M.P. 1995. The relationship between JIT manufacturing and performance in Mexican plants affiliated with US companies. Journal of Operations Management, 13(1), pp. 3-18.

[29] Lee, B. \& Barua, A. 1999. An integrated assessment of productivity and efficiency impacts of information technology investments: Old data, new analysis and evidence. Journal of Productivity Analysis, 12(1), pp. 21-43.

[30] Lieberman, M.B. \& Demeester, L. 1999. Inventory reduction and productivity growth: linkages in the Japanese automotive industry. Management Science, 45(4), pp. 466-485.

[31] Martin, R., Muûls, M., de Preux, L.B. \& Wagner, U.J. 2012. Anatomy of a paradox: Management practices, organizational structure and energy efficiency. Journal Of Environmental Economics and Management, 63(2), pp. 208-223. 
[32] Mital, A., Pennathur, A., Huston, R., Thompson, D., Pittman, M., Markle, G., Kaber, D., Crumpton, L., Bishu, R. \& Rajurkar, K. 1999. The need for worker training in advanced manufacturing technology (AMT) environments: A white paper. International Journal of Industrial Ergonomics, 24(2), pp. 173-184.

[33] Mukherjee, A., Mitchell, W. \& Talbot, F.B. 2000. The impact of new manufacturing requirements on production line productivity and quality at a focused factory. Journal of Operations Management, 18(2), pp. 139-168.

[34] Nitzan, D. \& Rosen, C.A. 1976. Programmable industrial automation. IEEE Transactions on Computers, 100(12), pp. 1259-1270.

[35] Noble, M.A. 1997. Manufacturing competitive priorities and productivity: An empirical study. International Journal of Operations \& Production Management, 17(1), pp. 85-99.

[36] Ornaghi, C. 2006. Spillovers in product and process innovation: Evidence from manufacturing firms. International Journal of Industrial Organization, 24(2), pp. 349-380.

[37] Park, C.-W., Kwon, K.-S., Kim, W.-B., Min, B.-K., Park, S.-J., Sung, I.-H., Yoon, Y.S., Lee, K.-S., Lee, J.-H. \& Seok, J. 2009. Energy consumption reduction technology in manufacturing - A selective review of policies, standards, and research. International Journal of Precision Engineering and Manufacturing, 10(5), pp. 151-173.

[38] Porter, M.E. 2000. Location, competition, and economic development: Local clusters in a global economy. Economic Development Quarterly, 14(1), pp. 15-34.

[39] Pun, K.-F. 2001. Cultural influences on total quality management adoption in Chinese enterprises: An empirical study. Total Quality Management, 12(3), pp. 323-342.

[40] Richards, D.J., Allenby, B.R. \& Frosch, R.A. 1994. The greening of industrial ecosystems: Overview and perspective. The greening of industrial ecosystems, pp. 1-19.

[41] Roach, S.S. 1988. Technology and the services sector: The hidden competitive challenge. Technological Forecasting and Social Change, 34(4), pp. 387-403.

[42] Schipper, L. \& Grubb, M. 2000. On the rebound? Feedback between energy intensities and energy uses in IEA countries. Energy Policy, 28(6), pp. 367-388.

[43] Schultz, K.L., Juran, D.C. \& Boudreau, J.W. 1999. The effects of low inventory on the development of productivity norms. Management Science, 45(12), pp. 1664-1678.

[44] Sharpe, A. 2002. Productivity concepts, trends and prospects: An overview. The Review of Economic Performance and Social Progress, 2.

[45] Shayan, E. \& Sobhanallahi, A. 2002. Productivity gains by cellular manufacturing. Production Planning \& Control, 13(6), pp. 507-516.

[46] Sohal, A.S. 1996. AMT investments in New Zealand: Purpose, pattern and outcomes. Integrated Manufacturing Systems, 7(2), pp. 27-36.

[47] Sohal, A.S., Moss, S. \& Ng, L. 2001. Comparing IT success in manufacturing and service industries. International Journal of Operations \& Production Management, 21(1/2), pp. 30-45.

[48] Soliman, F., Clegg, S. \& Tantoush, T. 2001. Critical success factors for integration of CAD/CAM systems with ERP systems. International Journal of Operations \& Production Management, 21(5/6), pp. 609-629.

[49] Syverson, C. 2010. What determines productivity? National Bureau of Economic Research.

[50] Terziovski, M. \& Sohal, A.S. 2000. The adoption of continuous improvement and innovation strategies in Australian manufacturing firms. Technovation, 20(10), pp. 539-550.

[51] Tseng, M.-L., Lin, Y.-H. \& Chiu, A.S. 2009. Fuzzy AHP-based study of cleaner production implementation in Taiwan PWB manufacturer. Journal of Cleaner Production, 17(14), pp. 1249-1256.

[52] Zhang, H.C., Kuo, T.C., Lu, H. \& Huang, S.H. 1997. Environmentally conscious design and manufacturing: A state-of-the-art survey. Journal of Manufacturing Systems, 16(5), pp. 352-371. 